\title{
Flattening the Glucocorticoid Rhythm causes Changes in Hippocampal Expression of Messenger RNAs Coding Structural and Functional Proteins: Implications for Aging and Depression
}

\author{
Sarah E Gartside*,', Melville M Leitch', Richard McQuade' and Daniel J Swarbrick' \\ 'Psychobiology Research Group, School of Neurology, Neurobiology and Psychiatry, The Medical School, Newcastle upon Tyne, UK
}

\begin{abstract}
Subtle changes in glucocorticoid levels, including a flattening of the diurnal rhythm with raised nadir, are prevalent, being characteristic of both aging and major depression. Both these conditions are also associated with deficits in hippocampally mediated cognitive functions. We hypothesized that this profile of glucocorticoid levels causes structural and functional changes in the hippocampus, which in turn may engender cognitive deficits. We implanted slow-release corticosterone pellets into adrenally intact adult male rats to produce a flattened glucocorticoid rhythm with levels clamped midway between the normal nadir and zenith. Using density profile analysis we measured hippocampal expression of messenger RNAs encoding structural and functional proteins. In rats with a flattened glucocorticoid rhythm, the expression of the mRNA coding for microtubule associated protein-2b (MAP2b) was reduced in CA3 relative to sham-operated controls, but unchanged in dentate gyrus and CAI. In contrast, the expression of the mRNA coding the alpha subunit of calciumcalmodulin dependent kinase (CAMKIl $\alpha$ ) was reduced in dentate gyrus in animals with a flattened glucocorticoid rhythm, but unchanged in CA3. The expression of the mRNA coding the synaptic vesicle protein synaptophysin was unchanged in both CA3 and dentate gyrus. The data indicate that a flattening of the normal diurnal glucocorticoid rhythm decreases the hippocampal expression of mRNAs coding key structural and functional proteins, and does so in a regionally selective manner. The data may have relevance for cognitive deficits characteristic of aging and depression.

Neuropsychopharmacology (2003) 28, 82 I-829, advance online publication, 5 March 2003; doi:I0.1038/sj.npp. I 300104
\end{abstract}

Keywords: corticosterone; hippocampus; microtubule associated protein-2; calcium-calmodulin dependent kinase; synaptophysin

\section{INTRODUCTION}

Over the past two decades it has become established that alterations in glucocorticoids can have dramatic influences on both the structure and the function of hippocampal neurons. Thus, morphological studies have revealed that either the administration of high doses of glucocorticoids or chronic stress induces the so-called 'dendritic pruning' in CA3 pyramidal neurons (Woolley et al, 1990; Magariños and McEwen 1995; McKittrick et al, 2000) as well as cell loss among the pyramidal neurons in CA3 and the granule cells of the dentate gyrus (Sousa et al, 1999; Haynes et al, 2001). It is also established that glucocorticoid excess decreases neurogenesis in the adult dentate gyrus (Gould and

\footnotetext{
* Correspondence: Dr SE Gartside, Psychiatry Research Laboratories, The Medical School, Framlington Place, Newcastle upon Tyne, NE2 4HH, UK, Tel: +44 191 222 7633, Fax: +44 191 222 5227, E-mail: sasha.gartside@ncl.ac.uk

Received 2 July 2002; revised 24 October 2002; accepted 29 October 2002

Online publication: 31 October 2002 at http://www.acnp.org/citations/ Npp 103102421
}

Tanapat, 1999). These structural effects are mirrored in an attenuation of long-term potentiation (LTP) (Pavlides et al, 1993; Smriga et al, 1996) and an impairment of hippocampally mediated spatial memory performance in rodents (Sousa et al, 2000). However, glucocorticoids show a Ushaped dose-response curve with respect to the structure and function of hippocampal neurons, and reduction or removal of circulating glucocorticoids by adrenalectomy (ADX) also has deleterious effects on hippocampus. Structural changes observed include a marked loss of granule cells (Sloviter et al, 1993, 1995; Gould et al, 1990), impoverishment of granule cell dendrites, and reduction in synapses between mossy fibers and the apical dendrites of CA3 pyramidal neurons (Sousa et al, 1999). ADX also attenuates both LTP (Smriga et al, 1996; Shors et al, 1990) and spatial working memory (McCormick et al, 1997).

While gross alterations in circulating glucocorticoids are characteristic of Cushing's and Addison's diseases, these disorders are uncommon. However, more subtle changes in glucocorticoid levels are comparatively prevalent, and furthermore often go untreated. Thus in the normal aging process, there is a significant flattening of the normal 
diurnal rhythm of cortisol secretion (Ferrari et al, 2001; Van Cauter et al, 1996; Deuschle et al, 1997a). In addition, several common psychiatric disorders including affective disorders, cortisol secretion is moderately increased and there is a marked flattening of the diurnal rhythm (Deuschle et al, 1997b; Ferrari et al, 2001).

Aging and affective disorders are associated with not only glucocorticoid abnormalities but also with cognitive impairments. Thus, in aging rodents there are impairments of hippocampally mediated spatial memory (Aitken and Meaney, 1989; Frick et al, 1995). Moreover, in elderly humans, there is also a recognized decline in memory function (Golomb et al, 1996; Mayeux et al, 2001). Interestingly, patients with affective disorders have also been shown to exhibit cognitive deficits including in mnemonic processing (for reviews see Christensen et al, 1997; Bearden et al, 1998). These impairments, in particular those in visuospatial memory, have been most consistently observed in severe unipolar depression (including melancholic and psychotic subtypes) as well as in bipolar disorder (Austin et al, 2001; Quraishi and Frangou, 2002). Recent evidence suggests that deficits may persist into clinical remission (Abas et al, 1990; Rubinsztein et al, 2000; Austin et al, 2001).

Given the established effects of glucocorticoids on the hippocampus reviewed above, a causal relation between disturbed glucocorticoid rhythm and altered hippocampal function in aged individuals and depressed patients may be suggested. However, the studies cited above have in general used very large doses of glucocorticoids or complete removal of glucocorticoids, and it remains unclear whether more moderate changes would cause similar effects. In the present study, we have sought to address the question of whether moderate changes in glucocorticoid secretion and rhythm of the sort seen in aging and psychiatric disorders might cause changes in hippocampal structure and function, which could in turn underlie cognitive deficits.

We have previously shown that implantation of slowrelease corticosterone pellets in adrenally intact adult rats produces a flattened glucocorticoid rhythm, in which levels are clamped midway between the normal morning nadir and evening peak, and there is no change in overall glucocorticoid exposure (Leitch et al, 2003). Here we used this model to determine the effects of flattened glucocorticoid rhythm on hippocampal expression of mRNAs coding for three neuronal proteins using in situ hybridization histochemistry. The mRNA species measured were those coding for (i) microtubule associated protein-2b (MAP2b)- a cytoskeletal protein, which is thought to play an important role in axonal and dendritic transport (Goedert $e t$ al, 1991); (ii) CAMKII $\alpha$ - the alpha subunit of a calcium dependent kinase known to show activity dependent changes in expression (Soderling and Derkach, 2000); and (iii) synaptophysin - a synaptic vesicle protein involved in vesicle biogenesis and fusion (Elferink and Scheller, 1995).

\section{METHODS}

\section{Animals}

Male Sprague-Dawley rats (Bantin and Kingman, Hull, UK) weighing approximately $160 \mathrm{~g}$ were brought into the local animal facility. Animals were group housed in controlled conditions of light $(12 \mathrm{~h}$ light/dark cycle, lights on at $7.00 \mathrm{am}$, temperature, and humidity, and were allowed food and water ad lib. Animals were allowed to acclimatize for 57 days. All studies were carried out within the guidelines of the UK Animals (Scientific Procedures) Act 1986.

\section{Corticosterone Treatment}

Four groups of eight animals were used. Animals were briefly anesthetised with isoflurane and a small incision was made in the skin overlying the flank. A subcutaneous pocket was made by separation of the skin from the subcutaneous tissue. Eight animals underwent sham surgery and eight animals had a $75 \mathrm{mg}$ 21-day slow-release corticosterone pellet (Innovative Research of America, USA) implanted. The skin wound was sutured, a subcutaneous injection of buprenorphine $(0.05 \mathrm{mg} / \mathrm{kg})$ was given in the scruff region, and animals were allowed to recover from the anesthetic. Animals were returned to their home cages (group housed) and moved to a recovery room with an ambient temperature of $25^{\circ} \mathrm{C}$ for $1-2$ days before being returned to the stock room. In some cases animals were supplied with watersoaked diet to encourage feeding.

On days 11, 12, and 13 following surgery, animals were briefly handled. Between 10.00 and $16.00 \mathrm{~h}$ before being killed, animals were moved in their home cages to the experimental room and left to acclimatise. Groups of sham-operated and implanted animals were killed at $7.00 \mathrm{pm}$ on day 14 and $8.00 \mathrm{am}$ on day 15 following surgery. Rats were removed one at a time from their home cages and quickly killed by guillotine. Trunk blood was collected for subsequent analysis of serum corticosterone. Brains were removed and snap frozen in isopentane cooled on dry ice. Brains were then stored at $-70^{\circ} \mathrm{C}$ until sectioning.

\section{Corticosterone Assay}

Trunk blood samples were left to coagulate on ice. They were then centrifuged and the resultant serum removed. Samples were stored at $-20^{\circ} \mathrm{C}$ until assay using a commercially available $\left[{ }^{125} \mathrm{I}\right]$ corticosterone radioimmunoassay (ICN, Orangeburg, USA).

\section{Preparation of Hippocampal Tissue for In Situ Hybridization Histochemistry}

Brains from the groups of sham-operated and implanted animals killed at $8.00 \mathrm{am}$ were sectioned using a cryostat. Sections of hippocampus $12 \mu \mathrm{m}$ thick were thaw mounted onto RNAase free gelatinized slides. Three sections per slide were collected. Slides were then stored frozen at $-70^{\circ} \mathrm{C}$ until fixation.

Sections were fixed according to the following protocol: fixation $5 \mathrm{~min}$ in $4 \%$ paraformaldehyde in phosphatebuffered saline (PBS), washing twice in PBS acetylated $10 \mathrm{~min}$ in $0.25 \%$ acetic anhydride in $0.1 \mathrm{M}$ triethanolamine buffer. Sections were then dehydrated through graded ethanol washes and then defatted by a 10 min chloroform wash. Finally, sections were treated with 100 and 95\% ethanol and air dried. Following fixation, sections were stored at $-20^{\circ} \mathrm{C}$. 


\section{In Situ Hybridization Histochemistry}

In situ hybridization histochemistry for MAP2b, CAMKII $\alpha$, and synaptophysin was performed on the slide mounted, pretreated, hippocampal sections. Probes against MAP2b and CAMKII $\alpha$ were designed in-house with reference to the published mRNA sequences using the GENBANK and BLAST facilities of NIH. The MAP2b probe was a 39-mer (sequence $5^{\prime} \mathrm{ctt}$ cct cac ctc gaa cct ctg ctg gtt cgg aca caa ctg $3^{\prime}$ ) targeted to base pairs $3781-3820$ of the mRNA transcript (Marechal et al, 1988; Kindler et al, 1990). The probe for CAMKII $\alpha$ was a 31 -mer $\left(5^{\prime}\right.$ cct ggt ccg gtc cca ggg acg cga gaa cga a $3^{\prime}$ ) targeting base pairs $1480-1510$ of the mRNA transcript (Lin et al, 1987). The probe for synaptophysin $\left(5^{\prime}\right.$ tag cct tgc tgc cca tag tcg ccc tga ggc ccg tag cca $3^{\prime}$ ) targeting base pairs $870-908$ of the mRNA transcript (Bargou and Leube, 1991) was taken from the literature (Eastwood et al, 1994). In each case a BLAST search against all published gene sequences was performed to confirm specificity of the probe. Oligonucleotide probes for MAP2b, CAMKII $\alpha$, and synaptophysin were synthesized by the molecular biology unit of Newcastle University.

Oligonucleotide probes were $3^{\prime}$ end labelled using $\left[{ }^{35} \mathrm{~S}\right]-$ ATP and terminal deoxynucleotidyl transferase (TdT) (Amersham). Labelled oligonucleotide was purified on a Sephadex G50 size exclusion column and was added to a hybridization mixture (comprising 50\% formamide, $4 \times$ standard saline citrate (SSC), $10 \%$ dextran sulfate, $5 \times$ Denhardts, $200 \mu \mathrm{g} / \mathrm{ml}$ salmon sperm DNA, $100 \mu \mathrm{g} / \mathrm{ml}$ poly A, $25 \mathrm{mM}$ sodium phosphate, $1 \mathrm{mM}$ sodium pyrophosphate, and 5\% dithiothreitol (Pei et al, 1998)). Hybridization mixture $\left(200 \mu \mathrm{l}\right.$ containing approximately $2 \times 10^{6} \mathrm{cpm}$ per slide) was pipetted onto each slide and was spread evenly. Slides were then coverslipped, and incubated overnight at $35^{\circ} \mathrm{C}$ in sealed boxes humidified with $50 \%$ formamide in $4 \times$ SSC.

Coverslips and excess hybridization mixture were washed off in $1 \times$ SSC. Slides then underwent three separate 20 -min washes in hot $1 \times \operatorname{SSC}\left(58^{\circ} \mathrm{C}\right)$, followed by two 60 -min washes in room temperature $1 \times$ SSC. Following a final rinse in deionised water, slides were air dried, mounted onto card and placed in a photographic cassette together with calibration strips (Amersham) containing known amounts of $\left[{ }^{14} \mathrm{C}\right]$. Biomax film (Kodak Eastman) was apposed to the slides for 1 week. Films were developed using an automated Agfa Curix compact plus daylight ${ }^{\mathrm{TM}}$ processor.

\section{Densitometry/Quantification}

Images from developed autoradiograms were captured on digital camera and stored for off-line analysis. Optical density readings were calibrated by reference to the $\left[{ }^{14} \mathrm{C}\right]$ standards and are expressed in arbitrary units of radioactivity. Analysis was performed using Scion Image software (NIH) and a density slice paradigm that was designed in-house (see Figure 1). Briefly, two brain sections per animal containing four hippocampi (two left, two right) were analyzed. A line was drawn freehand along the cell body region of the hippocampal subfield of interest, and 4-7 lines of 100 pixels perpendicular to and centered on the freehand line were generated. The calibrated density in each of these pixels for each of the 4-7 perpendiculars was

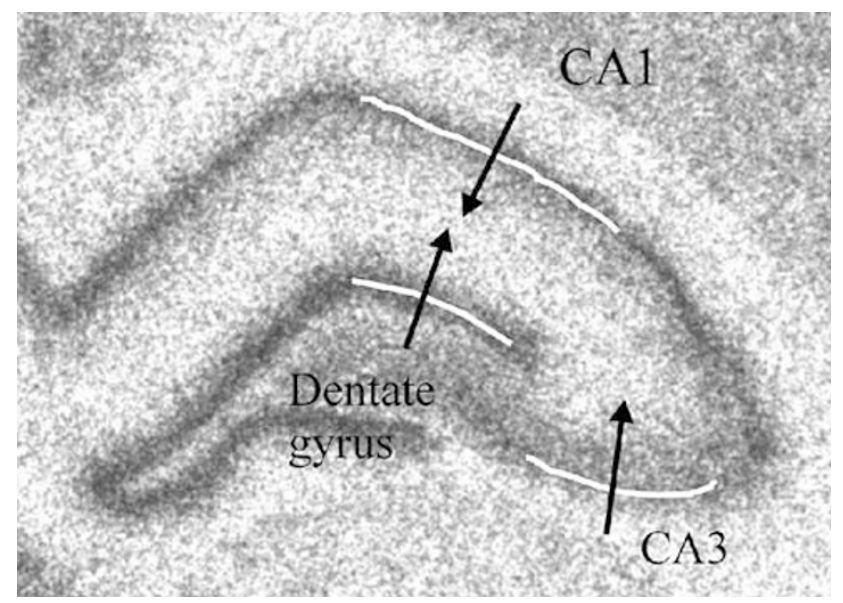

Figure I Typical autoradiogram for MAP2b mRNA showing the regions used for density profile analysis. White lines indicate the approximate extent of the cell layer in each region for which density profiles were determined. Arrows indicate the direction of the profile and the approximate length of the profile through the cell body and dendritic layers.

determined. This procedure was repeated three times for each hippocampus. Density profiles from the four hippocampi were averaged to produce one density profile per animal. Density profiles were trimmed to a length appropriate to the cell layer under study.

\section{Data Analysis and Statistics}

Density profile data were analyzed by two-way repeated measures split-plot ANOVA with pixels grouped into bins containing five adjacent pixels. Significant main effects (treatment and bin) and treatment $\times$ bin interactions are quoted. Post hoc analysis on individual bins was by two-way repeated measures ANOVA on the five pixels within each bin. Data quoted in the text and shown in the figures are mean $\pm \operatorname{SEM}(n)$. Statistical significance at the $95 \%$ level and above is reported.

\section{RESULTS}

\section{Serum Corticosterone}

In sham-operated animals, corticosterone levels showed diurnal variation being high at $7.00 \mathrm{pm}(8.97 \pm 2.0 \mu \mathrm{g} / \mathrm{dl})$ and low at $8.00 \mathrm{am}(0.6 \pm 0.08 \mu \mathrm{g} / \mathrm{dl})$. In implanted animals, corticosterone levels were at a level midway between the am and $\mathrm{pm}$ values of the sham-operated animals and did not differ between the two time points (am: $4.63 \pm 0.75$; pm: $4.84 \pm 0.62 \mu \mathrm{g} / \mathrm{dl})$.

\section{Distribution of Synaptophysin, MAP2b, and CAMKII $\alpha$ mRNAs}

Figure 1 shows a typical MAP2b autoradiogram with the regions used for density profile analysis marked (see Methods). Figure 2 shows the distribution of mRNAs for MAP2b, CAMKII $\alpha$, and synaptophysin, in the hippocampus together with a cresyl violet (Nissl) stained section for comparison. All three mRNA species were densely expressed in Ammon's horn and the dentate gyrus; however, 


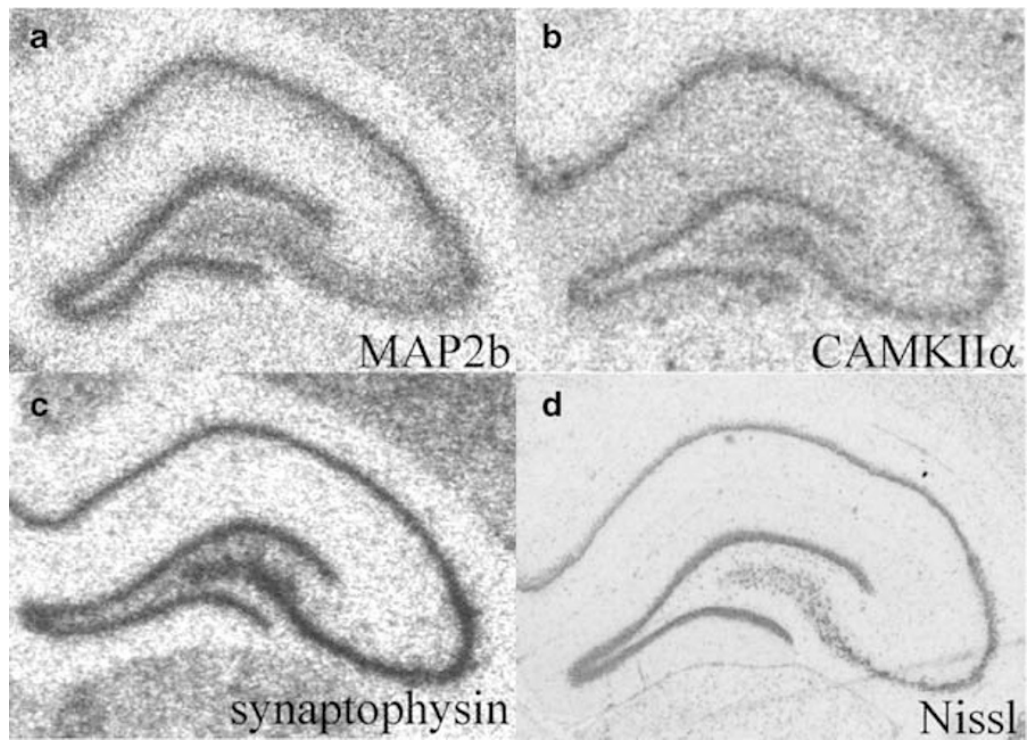

Figure 2 Expression of mRNAs for (a) MAP2b, (b) CAMKII $\alpha$, and (c) synaptophysin in the hippocampus of a sham-operated animal together with (d) a cresyl violet (Nissl) stained section for comparison. Note that while the expression of synaptophysin mRNA is restricted to cell body layers in Ammon's horn and dentate gyrus, that of MAP2b mRNA extends beyond the cell body layers into the area occupied by proximal portions of the apical dendrites of Ammon's horn and the mossy fibers of the dentate gyrus. Expression of CAMKIl $\alpha$ mRNA is clearly discernable throughout the extent of the apical dendrites of Ammon's horn and mossy fibers of the dentate gyrus.

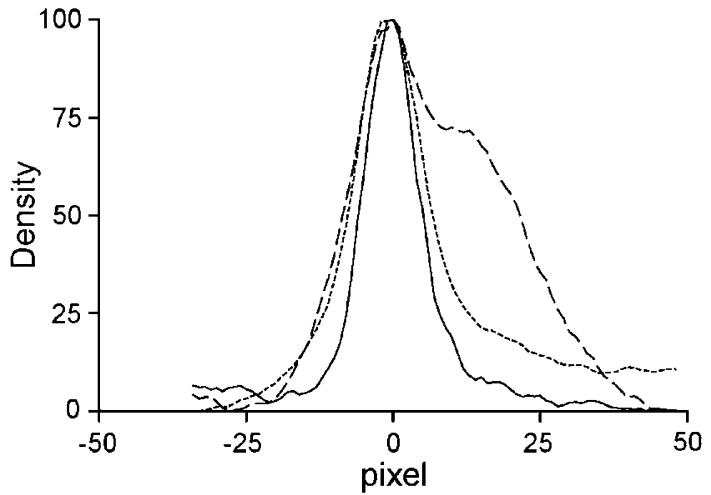

Figure 3 Representative density profiles taken across the CA3 region of Ammon's horn for the mRNAs coding MAP2b (dashed line), CAMKIll (dotted line), and synaptophysin (solid line). Data are normalised and expressed in arbitrary units of density with 100 as the maximal density and 0 as the minimum. Note the narrow peak of synaptophysin mRNA expression representing expression restricted to the cell body layer. The profile for CAMKIl $\alpha$ mRNA is wider and there is significant expression extending through the apical dendrites. The profile for MAP2b mRNA expression shows a double hump reflecting the expression of this species in the cell body layer as well as in a relatively restricted area of the proximal portion of the apical dendrites.

there were marked differences in their subcellular distributions. MAP2b mRNA (Figure 2a) expression appeared as a broad band in Ammon's horn and in the DG representing areas occupied by both cell bodies and proximal portions of the dendrites. Expression of CAMKII $\alpha$ mRNA was broader than that of MAP2b in both Ammon's horn and the DG with a discernable signal extending throughout the area occupied by the proximal and distal apical dendrites of the pyramidal cells and the mossy fibers of the granule cells (Figure $2 b$ ). In contrast, the distribution of synaptophysin mRNA (Figure 2c) was restricted to narrow bands representing the area of cell bodies of pyramidal and granule cells in CA1-4 and the DG, respectively.

Figure 3 shows representative density profiles for the MAP2b mRNA, CAMKII $\alpha$ mRNA, and synatophysin mRNA taken across the CA3 region of Ammon's horn. These density profiles clearly show the differences in subcellular distribution of the three mRNA species evident in Figure 2.

\section{Effect of Flattened Corticosterone Rhythm on the Expression of mRNAs Coding for MAP2b, CAMKII $\alpha$, and Synaptophysin}

$M A P 2 b$. As noted above, MAP2b mRNA expression in CA3 occurred as a broad band, which is represented on the density profile by a broad peak with a marked shoulder. In the corticosterone-implanted animals, expression of MAP2b mRNA showed selective reduction across the peak and the shoulder, that is, in areas representing both the cell bodies and proximal dendrites (Figure 4a). Repeated measures split-plot ANOVA of these data revealed a significant bin $\times$ treatment interaction $\left(\mathrm{F}_{16,224}=1.8, p<0.05\right)$ as well as a significant main effect of bin $\left(\mathrm{F}_{16,224}=328, p<0.001\right)$. Post hoc ANOVA showed no treatment differences in individual bins.

In the dentate gyrus, expression of MAP2b mRNA showed a broad peak, although without the marked shoulder observed in CA3. In this region there was no significant difference in MAP2b mRNA expression between corticosterone-implanted and sham-operated animals (Figure $4 \mathrm{~b}$ ). ANOVA showed no significant main effect of treatment and no bin $\times$ treatment interaction. Again a significant main effect of bin was noted $\left(\mathrm{F}_{16,208}=504, p<0.001\right)$.

The density profile for MAP $2 \mathrm{~b}$ mRNA in CA1 showed a much narrower peak than in CA3 but with a marked tailing into the stratum radiatum to the left-hand side of the profile. There was no difference in expression of MAP $2 b$ 

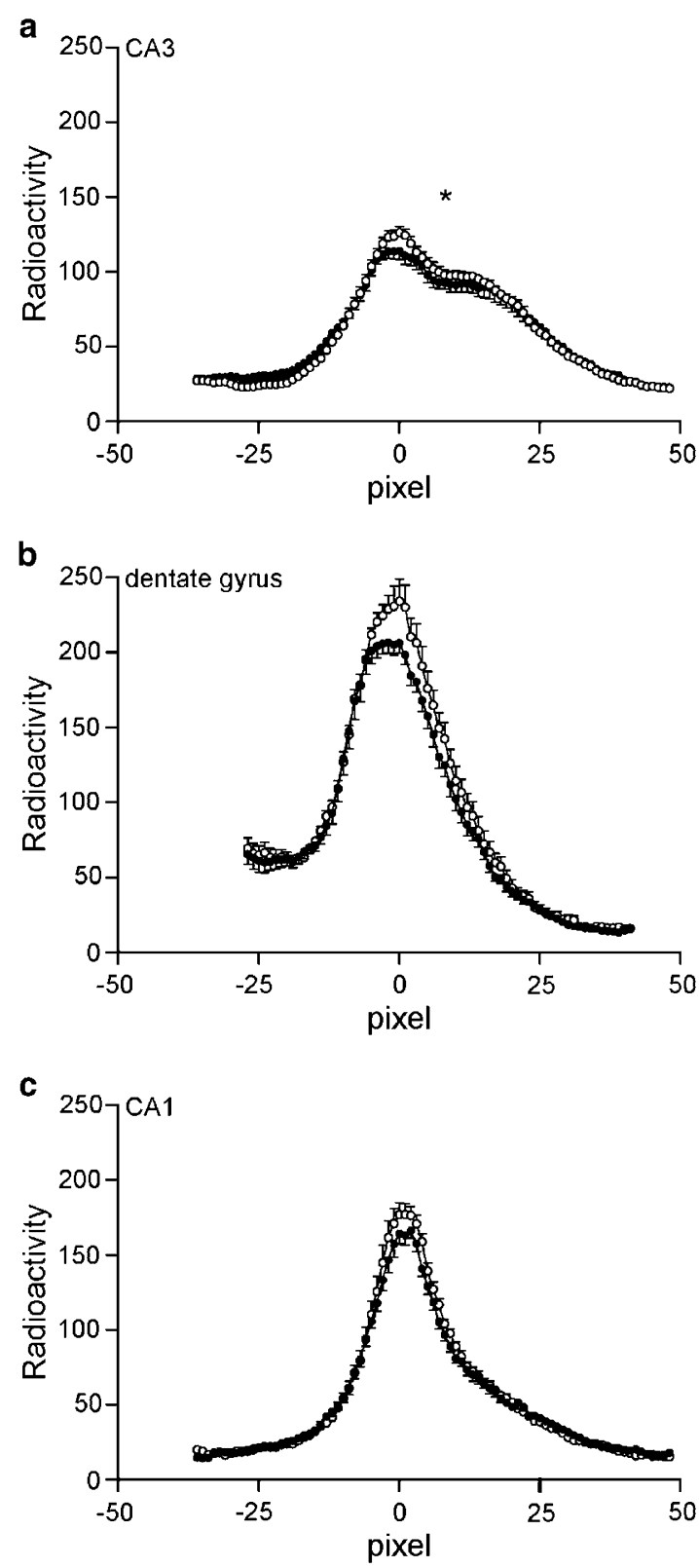

Figure 4 Density profiles for MAP2b mRNA expression in (a) CA3, (b) dentate gyrus, and (c) CAl in sham-operated (open symbols) and corticosterone-implanted animals (solid symbols). Data are mean + SEM ( $n=8$ per group). * indicates significant bin $\times$ treatment interaction. See text for full statistical analysis.

mRNA between corticosterone-implanted and sham-operated animals in CA1 (Figure 4c). Thus ANOVA of these data revealed no significant effect of treatment or treatment $\times$ bin interaction, but a significant main effect of bin $\left(\mathrm{F}_{16,208}=504, p<0.001\right)$.

CAMKII. The density profile of CAMKII $\alpha$ mRNA expression in CA3 shows a peak, which is narrower than that of MAP2 but which has marked tails extending well into the stratum radiatum (Figure 5a). In CA3 the expression of CAMKII $\alpha$ mRNA did not differ between implanted and sham-operated animals. Thus, ANOVA revealed no effect of treatment and no treatment $\times$ bin interaction, although a

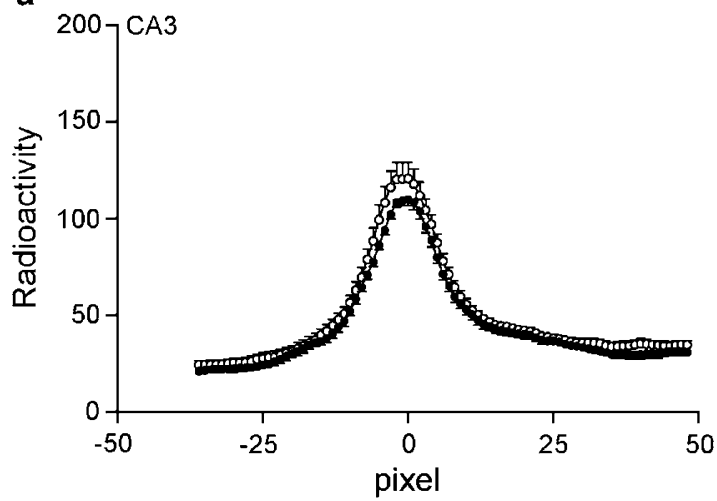

b

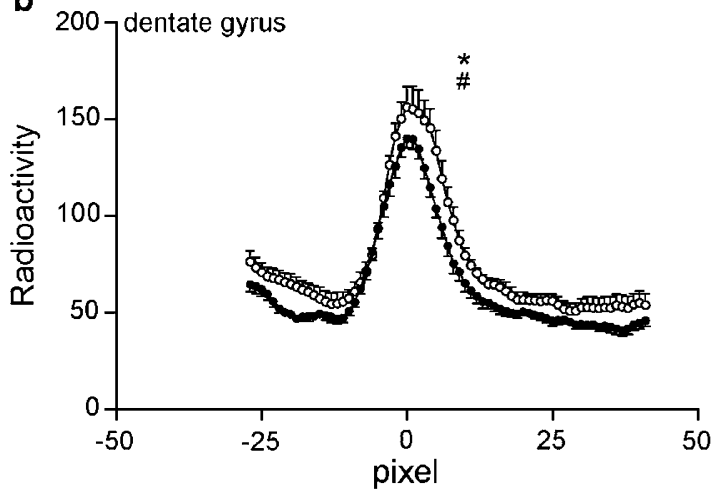

Figure 5 Density profiles for CAMKIl $\alpha$ mRNA expression in (a) CA3 and (b) dentate gyrus in sham-operated (open symbols) and corticosterone implanted animals (solid symbols). Data are mean \pm SEM ( $n=8$ per group). \# indicates significant treatment effect and $*$ indicates significant bin $\times$ treatment interaction. See text for full statistical analysis.

there was a highly significant main effect of bin $\left(\mathrm{F}_{16,224}=394, p<0.001\right)$.

The profile of CAMKII $\alpha$ mRNA expression in dentate gyrus in implanted and sham-operated animals is shown in Figure 5b. In the implanted animals, expression of the mRNA was reduced over much of the area measured. Thus ANOVA revealed a significant main effect of treatment $\left(\mathrm{F}_{1,14}=4.8, \quad p<0.05\right)$, and a significant treatment $\times$ bin interaction $\left(\mathrm{F}_{12,168}=2.2, p<0.05\right)$. Again there was a significant main effect of bin $\left(F_{12,168}=212, p<0.01\right)$. Post hoc ANOVA revealed that three bins representing the area of peak expression as well as a single bin representing the area between the blades of the dentate gyrus were significantly different between the two treatment groups (see Figure $5 b$ ).

Synaptophysin. The expression of synaptophysin mRNA in $\mathrm{CA} 3$ and dentate gyrus in corticosterone implanted and sham-operated animals is shown in Figures 6a and b. As noted above, synaptophysin mRNA was limited to a narrow band in these regions. Corticosterone treatment failed to alter the expression of synaptophysin mRNA in either region.

\section{DISCUSSION}

Here we sought to address the question of whether flattened glucocorticoid rhythm induces changes in hippocampal 

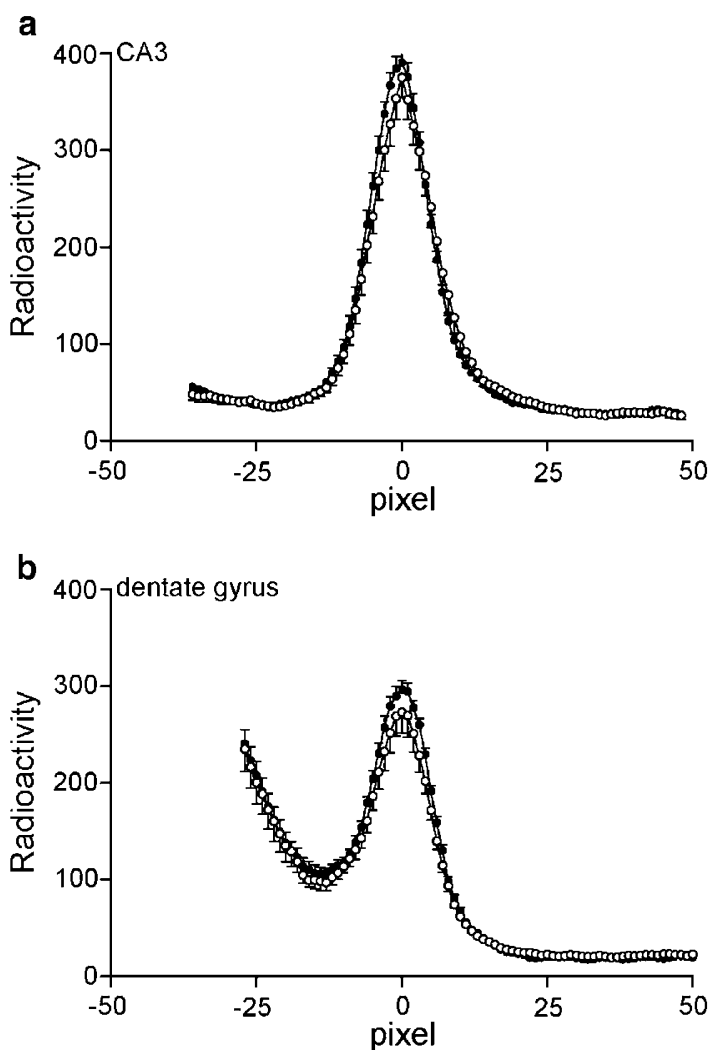

Figure 6 Density profiles for synaptophysin mRNA expression in (a) CA3 and (b) dentate gyrus in sham-operated (open symbols) and corticosterone-implanted animals (solid symbols). Data are mean \pm SEM $(n=8$ per group). See text for statistical analysis.

structure and function and hence might be causative in cognitive deficits. We used a previously validated rat model of flattened glucocorticoid rhythm, with raised nadir and lowered peak, and examined the effect of this manipulation on a number of mRNA species in the hippocampus using a specially developed density profile analysis. In animals with flattened corticosterone rhythm, we found that mRNAs for MAP2b and CAMKII were reduced in a regionally specific manner. Thus MAP2b mRNA was reduced in CA3 but not CA1 or dentate gyrus, while CAMKII $\alpha$ mRNA was reduced in dentate gyrus but not CA3. The expression of synaptophysin mRNAs was not modified in either CA3 or dentate gyrus. That the changes observed are selective with respect to both mRNA species and the hippocampal region suggest that loss of corticosterone rhythm causes specific changes in these mRNA species rather than loss of neurons or a generalized decrease in hippocampal volume.

\section{Density Profile Analysis}

In the present study we found that the expression of MAP2b, CAMKII, and synaptophysin mRNAs was high in the cell body regions of CA3, CA1, and dentate gyrus. While synaptophysin mRNA was limited to the cell body layers, MAP2b mRNA was moderately high in the regions occupied by the proximal portions of apical dendrites of pyramidal cells (CA1 and CA3) and mossy fibers in the molecular layer. Expression of the mRNA for CAMKII was moderate throughout the dendritic regions of Ammon's horn and the dentate gyrus. These findings are in accord with previous reports on the distributions of these mRNAs in the hippocampus (Paradies and Steward, 1997; Roberts et al, 1998; Crispino et al, 1999). Here we developed a density profile analysis to express these differing distributions numerically; this also provided a powerful method with which to compare expression of the mRNA species between treatment groups. Given the large number of individual data points (pixels), we controlled for type 1 error by using a split-plot analysis (grouping pixels into bins containing five adjacent pixels) and considered only significant bin, treatment, and treatment $\times$ bin effects. Using this type of analysis, it is possible to localize tentatively the subcellular regions in which changes may occur without the need for emulsion dipping or other labor intensive methods.

\section{Corticosterone-Induced Changes in Hippocampal Expression of mRNAs}

$M A P 2 b$. In corticosterone-implanted animals we found that the expression of the mRNA for MAP2b was reduced in CA3. There was also a trend towards a reduction in the dentate gyrus (suprapyramidal blade), although this was not statistically significant. Examination of the profile of MAP2b mRNA expression in CA3 in the two groups showed that corticosterone treatment reduced expression in both the cell body layer, and the proximal portions of the apical dendrites of pyramidal cells. The decrease in MAP2 mRNA in CA3 observed here is likely to be accompanied by reduced expression of MAP2b protein in this region, since treatments that alter MAP2b mRNA are frequently shown to alter the protein as well (see below). MAP2b is the adult dendritic form of a microtubule-associated protein that promotes the assembly and stability of microtubules. Hence, in mature neurons, MAP2b is critically involved in dendritic transport (Goedert et al, 1991). Data from previous studies indicate that treatments that increase dendritic arborization increase both MAP2 mRNA and MAP2 protein expression. Thus, seizure activity induces dendritic arborizations (Kato et al, 2001; Represa et al, 1993) and an increase in MAP2 mRNA and protein (Pollard et al, 1994; Pei et al, 1998; Kato et al, 2001). Kindling, and other seizure activity, is associated with an increase in synaptic strength (Trommer et al, 1994), suggesting that changes in MAP2 expression may have functional as well as structural correlates. In accord with this, an increased MAP2 mRNA expression in the dentate gyrus has been reported following the successful induction of perforant path LTP. Previous studies using high doses of glucocorticoids as well as chronic stress have shown the so-called dendritic pruning in CA3 apical dendrites with a decrease in overall length as well as in the number of branch points (Woolley et al, 1990; Magariños and McEwen, 1995). Our present data showing a CA3 selective decrease in MAP2 mRNA expression would be consistent with a decrement in dendritic extent and/or synaptic strength. Interestingly, Kuroda and McEwen (1998) reported that a chronic stress paradigm, which had previously been shown to cause pruning, was without effect on hippocampal MAP2 mRNA. However, it may be that the density profile analysis used in the present study has greater sensitivity to reveal small 
changes than the gross region of interest analysis used by Kuroda and McEwen (1998).

CAMKII $m R N A$. The hippocampal expression of CAMKII $\alpha$ mRNA was also decreased; however, there were qualitative differences from the changes in MAP2 mRNA. Thus, there was a reduction in expression in the dentate gyrus; however, this was not localized to cell body or dendritic regions but was apparent throughout the density profile. Furthermore, CAMKII $\alpha$ mRNA was unaltered in the CA3 region. CAMKII is a calmodulin-dependent kinase enzyme, which plays a critical role in LTP (Soderling and Derkach, 2000) and has been suggested to be the prime candidate for the molecular basis of memory (Lisman et al, 2002). CAMKII mRNA expression has been shown to be increased in dentate gyrus (molecular and granule cell layers) following perforant path LTP (Roberts et al, 1998) and increased in CA1 following Schaffer collateral induced LTP (Liu et al, 1999). Interestingly, mice with a mutant CAMKII show alterations in the frequency dependence of LTP induction (Hinds et al, 1998) together with deficits in spatial memory (Silva et al, 1996). The decrease found here was confined to the dentate gyrus and is perhaps indicative of reduced excitatory synaptic activity in this region either in excitatory inputs from the entorhinal cortex via the perforant path or outputs via synapses between mossy fibers and CA3 apical dendrites.

Synaptophysin mRNA. In the present study we found no changes in expression of the mRNA for synaptophysin in animals with a flattened corticosterone rhythm. Synaptophysin - a synaptic protein with roles in vesicle biogenesis and fusion (Elferink and Scheller, 1995) - is a wellestablished synaptic marker (Walaas et al, 1988; Eastwood and Harrison, 1995). Furthermore, it has been shown that synaptophysin protein correlates well with synaptic number when this is measured by morphometric methods (McEwen et al, 1999; Brake et al, 2001), and also that synaptophsyin mRNA correlates with synaptophysin protein levels (see Eastwood and Harrison, 1995). We reasoned that changes in neurotransmission in the hippocampus as a result of the corticosterone treatment might be expected to be associated with changes in synaptophysin. For example, dendritic pruning in CA3 may result in a decrease in synaptic contacts of CA3 neurons (apical dendrites) with mossy fibers. Such an effect might be expected to result in a decrease in synaptophysin mRNA in dentate granule cells. Contrary to this hypothesis, we found that synaptophysin mRNA was unaltered dentate gyrus and indeed was also unchanged in CA3. In a recent report it was shown that both acute and chronic restraint stress markedly reduced synaptophysin mRNA in hippocampus (Thome et al, 2001). These data suggest a role for corticosterone in the regulation of synaptophysin mRNA, but may indicate that such regulation occurs only with the magnitude of increase in corticosterone associated with restraint stress rather than with the moderate changes to the corticosterone rhythm used here.

\section{Relevance to Aging and Depression}

As discussed in the Introduction, moderate disturbances in glucocorticoid levels, including a flattening of the diurnal rhythm with raised nadir, are prevalent in normal aging as well as in depression. In the present study, we used a manipulation that produces glucocorticoid levels that are clamped at the midpoint of the diurnal rhythm and hence are increased at the nadir but decreased at the zenith relative to the normal rhythm. The corticosterone profile generated is very similar to that seen in aged rats (Hauger $e t$ al, 1994) and similar to the profile of cortisol levels in aged human subjects (Deuschle et al, 1997a; Ferrari et al, 2001; Van Cauter et al, 1996; Wong et al, 2000). The elevated nadir and flattened rhythm is also consistent with the pattern observed in depressed patients, although in this group the peak of the diurnal rhythm is preserved, or even marginally elevated, resulting in an increase in $24 \mathrm{~h}$ cortisol exposure (Deuschle et al, 1997b; Wong et al, 2000). Aging and depressive illnesses are both accompanied by cognitive deficits, including impairments in aspects of memory function (Golomb et al, 1996; Mayeux et al, 2001; Austin et al, 2001; Quraishi and Frangou, 2002), which are believed to be hippocampally mediated (Silva et al, 1998). Our present findings suggest that in these conditions, it may be the alteration in glucocorticoids that underlies these deficits in hippocampal function, although we are unable to firmly attribute the changes to raised nadir, lowered zenith, or flattened rhythm. Interestingly, it has recently been reported that patients with bipolar disorder have decreased CAMKII in the prefrontal cortex at postmortem (Xing et al, 2002). Although data on cortisol levels were not available, it is established that this group of patients is at high risk of cortisol abnormalities of the type modelled here (Cervantes et al, 2001; Yehuda et al, 1993).

\section{Conclusions}

In the present study we have observed that a flattening of the glucocorticoid rhythm, to a level between the normal nadir and zenith, without a change in overall glucocorticoid exposure, induces decreases in the hippocampal expression of mRNAs in a regionally selective manner. The data may have relevance for cognitive deficits characteristic of aging and depression.

\section{ACKNOWLEDGMENTS}

The authors are grateful to Mr Harvey Smith for his invaluable assistance in data processing. DJS was supported by a grant from the Wolfson Fellowship.

\section{REFERENCES}

Abas MA, Sahakian BJ, Levy R (1990). Neuropsychological deficits and CT scan changes in elderly depressives. Psychol Med 20: 507-520.

Aitken DH, Meaney MJ (1989). Temporally graded, age-related impairments in spatial memory in the rat. Neurobiol Aging 10: 273-276.

Austin MP, Mitchell P, Goodwin GM (2001). Cognitive deficits in depression: possible implications for functional neuropathology. Br J Psychiatry 178: 200-206.

Bargou RC, Leube RE (1991). The synaptophysin-encoding gene in rat and man is specifically transcribed in neuroendocrine cells. Gene 99: 197-204. 
Bearden CE, Hoffman KM, Cannon TD (1998). The neuropsychology and neuroanatomy of bipolar affective disorder: a critical review. Bipolar Disord 3: 106-150.

Brake WG, Alves SE, Dunlop JC, Lee SJ, Bulloch K, Allen PB et al (2001). Novel target sites for estrogen action in the dorsal hippocampus: an examination of synaptic proteins. Endocrinology 142: 1284-1289.

Cervantes P, Gelber S, Kin FN, Nair VN, Schwartz G (2001). Circadian secretion of cortisol in bipolar disorder. J Psychiatry Neurosci 26: 411-416.

Christensen H, Griffiths K, Mackinnon A, Jacomb P (1997). A quantitative review of cognitive deficits in depression and Alzheimer-type dementia. J Int Neuropsychol Soc 3: 631-651.

Crispino M, Stone DJ, Wei M, Anderson CP, Tocco G, Finch CE et al (1999). Variations of synaptotagmin I, synaptotagmin IV, and synaptophysin mRNA levels in rat hippocampus during the estrous cycle. Exp Neurol 159: 574-583.

Deuschle M, Gotthardt U, Schweiger U, Weber B, Korner A, Schmider J et al (1997a). With aging in humans the activity of the hypothalamus-pituitary-adrenal system increases and its diurnal amplitude flattens. Life Sci 61: 2239-2246.

Deuschle M, Schweiger U, Weber B, Gotthardt U, Korner A, Schmider J et al (1997b). Diurnal activity and pulsatility of the hypothalamus-pituitary-adrenal system in male depressed patients and healthy controls. J Clin Endocrinol Metab 82: 234-238.

Eastwood SL, Burnet PW, McDonald B, Clinton J, Harrison PJ (1994). Synaptophysin gene expression in human brain: a quantitative in situ hybridization and immunocytochemical study. Neuroscience 59: 881-92.

Eastwood SL, Harrison PJ (1995). Decreased synaptophysin in the medial temporal lobe in schizophrenia demonstrated using immunoautoradiography. Neuroscience 69: 339-343.

Elferink LA, Scheller RH (1995). Synaptic vesicle proteins and regulated exocytosis. Prog Brain Res 105: 79-85.

Ferrari E, Cravello L, Muzzoni B, Casarotti D, Paltro M, Solerte SB et al (2001). Age-related changes of the hypothalamic-pituitaryadrenal axis: pathophysiological correlates. Eur J Endocrinol 144: 319-329.

Frick KM, Baxter MG, Markowska AL, Olton DS, Price DL (1995). Age-related spatial reference and working memory deficits assessed in the water maze. Neurobiol Aging 16: 149-160.

Goedert M, Crowther RA, Garner CC (1991). Molecular characterization of microtubule-associated proteins tau and MAP2. Trends Neurosci 14: 193-199.

Golomb J, Kluger A, de Leon MJ, Ferris SH, Mittelman M, Cohen J et al (1996). Hippocampal formation size predicts declining memory performance in normal aging. Neurology 47: 810-813.

Gould E, Tanapat P (1999). Stress and hippocampal neurogenesis. Biol Psychiatry 46: 1472-1479.

Gould E, Woolley CS, McEwen BS (1990). Short-term glucocorticoid manipulations affect neuronal morphology and survival in the adult dentate gyrus. Neuroscience 37: 367-375.

Hauger RL, Thrivikraman KV, Plotsky PM (1994). Age-related alterations of hypothalamic-pituitary-adrenal axis function in male Fischer 344 rats. Endocrinology 134: 1528-1536.

Haynes LE, Griffiths MR, Hyde RE, Barber DJ, Mitchell IJ (2001). Dexamethasone induces limited apoptosis and extensive sublethal damage to specific subregions of the striatum and hippocampus: implications for mood disorders. Neuroscience 104: 57-69.

Hinds HL, Tonegawa S, Malinow R (1998). CA1 long-term potentiation is diminished but present in hippocampal slices from alpha-CaMKII mutant mice. Learn Mem 5: 344-354.

Kato K, Masa T, Tawara Y, Kobayashi K, Oka T, Okabe A et al (2001). Dendritic aberrations in the hippocampal granular layer and the amygdalohippocampal area following kindled-seizures. Brain Res 901: 281-295.
Kindler S, Schwanke B, Schulz B, Garner CC (1990). Complete cDNA sequence encoding rat high and low molecular weight MAP2. Nucleic Acids Res 18: 2822.

Kuroda Y, McEwen BS (1998). Effect of chronic restraint stress and tianeptine on growth factors, growth-associated protein-43 and microtubule-associated protein 2 mRNA expression in the rat hippocampus. Brain Res Mol Brain Res 59: 35-39.

Leitch MM, Ingram $\mathrm{CD}$, Young $\mathrm{AH}$, McQuade R, Gartside SE (2003). Flattening the corticosterone rhythm attenuates 5HT(1A) autoreceptor function in the rat: relevance for depression. Neuropsychopharmacology 28: 119-122.

Lin CR, Kapiloff MS, Durgerian S, Tatemoto K, Russo AF, Hanson $\mathrm{P}$ et al (1987). Molecular cloning of a brain-specific calcium/ calmodulin-dependent protein kinase. Proc Natl Acad Sci USA 84: $5962-5966$

Lisman J, Schulman H, Cline H (2002). The molecular basis of CaMKII function in synaptic and behavioural memory. Nat Rev Neurosci 3: 175-190.

Liu J, Fukunaga K, Yamamoto H, Nishi K, Miyamoto E (1999). Differential roles of $\mathrm{Ca}(2+) /$ calmodulin-dependent protein kinase II and mitogen-activated protein kinase activation in hippocampal long-term potentiation. J Neurosci 19: 8292-8299.

Magariños AM, McEwen BS (1995). Stress-induced atrophy of apical dendrites of hippocampal CA3c neurons: involvement of glucocorticoid secretion and excitatory amino acid receptors. Neuroscience 69: 89-98.

Marechal D, Delapierre D, Dresse A (1988). Cloning and partial sequencing of a new rat brain specific cDNA. Arch Int Physiol Biochim 96: 231-236.

Mayeux R, Small SA, Tang M, Tycko B, Stern Y (2001). Memory performance in healthy elderly without Alzheimer's disease: effects of time and apolipoprotein-E. Neurobiol Aging 22: 683689.

McCormick CM, McNamara M, Mukhopadhyay S, Kelsey JE (1997). Acute corticosterone replacement reinstates performance on spatial and nonspatial memory tasks 3 months after adrenalectomy despite degeneration in the dentate gyrus. Behav Neurosci 111: 518-531.

McEwen BS, Tanapat P, Weiland NG (1999). Inhibition of dendritic spine induction on hippocampal CA1 pyramidal neurons by a nonsteroidal estrogen antagonist in female rats. Endocrinology 140: 1044-1047.

McKittrick CR, Magarinos AM, Blanchard DC, Blanchard RJ, McEwen BS, Sakai RR (2000). Chronic social stress reduces dendritic arbors in CA3 of hippocampus and decreases binding to serotonin transporter sites. Synapse 36: 85-94.

Paradies MA, Steward O (1997). Multiple subcellular mRNA distribution patterns in neurons: a nonisotopic in situ hybridization analysis. J Neurobiol 33: 473-493.

Pavlides C, Watanabe Y, McEwen BS (1993). Effects of glucocorticoids on hippocampal long-term potentiation. Hippocampus 3: 183-192.

Pei Q, Burnet PJW, Zetterstrom TSC (1998). Changes in mRNA abundance of microtubule-associated proteins in the rat brain following electroconvulsive shock. Neuroreport 9: 391-394.

Pollard H, Khrestchatisky M, Moreau J, Ben-Ari Y, Represa A (1994). Correlation between reactive sprouting and microtubule protein expression in epileptic hippocampus. Neuroscience 61: 773-787.

Quraishi S, Frangou S (2002). Neuropsychology of bipolar disorder: a review. J Affect Disord 72: 209-226.

Represa A, Pollard H, Moreau J, Ghilini G, Khrestchatisky M, BenAri Y (1993). Mossy fiber sprouting in epileptic rats is associated with a transient increased expression of alpha-tubulin. Neurosci Lett 156: 149-152.

Roberts LA, Large CH, Higgins MJ, Stone TW, O'Shaughnessy CT, Morris BJ (1998). Increased expression of dendritic mRNA 
following the induction of long-term potentiation. Brain Res $\mathrm{Mol}$ Brain Res 56: 38-44.

Rubinsztein JS, Michael A, Paykel ES, Sahakian BJ (2000). Cognitive impairment in remission in bipolar affective disorder. Psychol Med 30: 1025-1036.

Shors TJ, Levine S, Thompson RF (1990). Effect of adrenalectomy and demedullation on the stress-induced impairment of longterm potentiation. Neuroendocrinology 51: 70-75.

Silva AJ, Giese KP, Fedorov NB, Frankland PW, Kogan JH (1998). Molecular, cellular, and neuroanatomical substrates of place learning. Neurobiol Learn Mem 70: 44-61.

Silva AJ, Rosahl TW, Chapman PF, Marowitz Z, Friedman E, Frankland PW et al (1996). Impaired learning in mice with abnormal short-lived plasticity. Curr Biol 6: 1509-1518.

Sloviter RS, Sollas AL, Dean E, Neubort S (1993). Adrenalectomyinduced granule cell degeneration in the rat hippocampal dentate gyrus: characterization of an in vivo model of controlled neuronal death. J Comp Neurol 330: 324-336.

Sloviter RS, Sollas AL, Neubort S (1995). Hippocampal dentate granule cell degeneration after adrenalectomy in the rat is not reversed by dexamethasone. Brain Res 682: 227-230.

Smriga M, Saito H, Nishiyama N (1996). Hippocampal long- and short-term potentiation is modulated by adrenalectomy and corticosterone. Neuroendocrinology 64: 35-41.

Soderling TR, Derkach VA (2000). Postsynaptic protein phosphorylation and LTP. Trends Neurosci 23: 75-80.

Sousa N, Lukoyanov NV, Madeira MD, Almeida OF, Paula-Barbosa MM (2000). Reorganization of the morphology of hippocampal neurites and synapses after stress-induced damage correlates with behavioral improvement. Neuroscience 97: 253-266.

Sousa N, Madeira MD, Paula-Barbosa MM (1999). Corticosterone replacement restores normal morphological features to the hippocampal dendrites, axons and synapses of adrenalectomized rats. J Neurocytol 28: 541-558.

Thome J, Pesold B, Baader M, Hu M, Gewirtz JC, Duman RS et al (2001). Stress differentially regulates synaptophysin and synaptotagmin expression in hippocampus. Biol Psychiatry 50: 809812.

Trommer BL, Pasternak JF, Nelson PJ, Colley PA, Kennelly JJ (1994). Perforant path kindling alters dentate gyrus field potentials and paired pulse depression in an age-dependent manner. Brain Res Dev Brain Res 79: 115-121.

Van Cauter E, Leproult R, Kupfer DJ (1996). Effects of gender and age on the levels and circadian rhythmicity of plasma cortisol. $J$ Clin Endocrinol Metab 81: 2468-2473.

Walaas SI, Jahn R, Greengard P (1988). Quantitation of nerve terminal populations: synaptic vesicle-associated proteins as markers for synaptic density in the rat neostriatum. Synapse 2: 516-520.

Wong ML, Kling MA, Munson PJ, Listwak S, Licinio J, Prolo P et al (2000). Pronounced and sustained central hypernoradrenergic function in major depression with melancholic features: relation to hypercortisolism and corticotropin-releasing hormone. Proc Natl Acad Sci USA 97: 325-330.

Woolley CS, Gould E, McEwen BS (1990). Exposure to excess glucocorticoids alters dendritic morphology of adult hippocampal pyramidal neurons. Brain Res 531: 225-231.

Xing G, Russell S, Hough C, O'Grady J, Zhang L, Yang S et al (2002). Decreased prefrontal CaMKII alpha mRNA in bipolar illness. Neuroreport 13: 501-505.

Yehuda R, Boisoneau D, Mason JW, Giller EL (1993). Glucocorticoid receptor number and cortisol excretion in mood, anxiety, and psychotic disorders. Biol Psychiatry 34: 18-25. 